\title{
MODEL KEPEMIMPINAN PENDIDIKAN MASA DEPAN BERBASIS AGAMA, FILSAFAT, PSIKOLOGI DAN SOSIOLOGI
}

\author{
Muhidin Arifin ${ }^{1}$, Ujang Nurjaman ${ }^{2}$ \\ ${ }^{1}$ Sekolah Pascasarjana Universitas Islam Nusantara, Bandung, Indonesia \\ Muhidinarifin@gmail.com \\ ${ }^{2}$ Sekolah Pascasarjana Universitas Islam Nusantara, Bandung, Indonesia \\ Ujangnurjaman@gmail.com
}

\begin{abstract}
Abstrak
Dewasa ini, dibutuhkan sosok pemimpin yang mampu memimpin dan menjadi teladan bagi bawahannya untuk bersama melakukan perubahan ke arah positif. Kepemimpinan merupakan suatu hal yang dinamis, berubah, dan berkembang sesuai masanya sehingga banyak konsep gaya kepemimpinan yang berkembang. Permasalahan dalam makalah ini adalah Dari uraian di atas dapat dirumuskan permasalahan dalam makalah ini, yaitu: Bagaimana Model kepemimpinan pendidikan masa depan berbasis agama, filsafat, psikologi, dan sosiologi. Tujuan dari penulisan makalah ini adalah untuk mengetahuii, menganalisis dan mendapatkan informasi model kepemimpinan pendidikan masa depan berbasis agama, filsafat, psikologi, dan sosiologi. Hasil kajian ini menyebutkan bahwa model kepemimpinan berbasis agama meletakkan dasar teologis yaoitu Alquran yang relative banyak memberikan karakteristik kepemimpinan, dari aspek filsafat kepemimpinan mengacu dalam beberapa prinsip Filsafat ini mengakui bahwa yang abadi adalah nilai-nilai dan bukan sesuatu yang kelihatan. Kehidupan manusia adalah perwujudan dari nilai-nilai yang abadi. Dalam filsafat nilai yang terpenting adalah esensi dari kehidupan manusia. Dari basis pskiologis kepemimpinan bersinggungan dengan optimism dan harapan, sedangkan dari basis sosiologis Pemimpin merupakan figur sentral dalam kelompok sosial atau masyarakat, sesuai dengan posisi yang ditempatinya dia memegang peran penting dalam mengatur kelangsungan hidup kelompok, seperti membina hubungan antar peribadi, menciptakan suasana yang harmonis, mengatasi ketegangan dan konflik.
\end{abstract}

Kata Kunci: Kepemimpinan, agama, filsafat, psikologis dan sosiologis

\section{PENDAHULUAN}

Dalam organisasi, dalam konteks makalah ini organisasi pendidikan, faktor kepemimpinan memegang peranan penting karena pemimpinlah yang akan menggerakkan dan mengarahkan organisasi dalam mencapai tujuan. Kepemimpinan merupakan suatu hal yang dinamis. Dewasa ini, dibutuhkan sosok pemimpin yang mampu memimpin dan menjadi teladan bagi bawahannya untuk bersama melakukan perubahan ke arah positif. Kepemimpinan merupakan bagian penting dari manajemen, namun tidak sama dengan manajemen. Islam memiliki tokoh panutan dalam melaksanakan kepemimpinan yaitu Nabi Muhammad. Kepemimpinanya menjadi tolak ukur yang dapat diterapkan pada setiap zaman. Nabi Muhammad telah mencontohkan bagaimana kepemimpinannya dapat berhasil.

Al Qalam: Jurnal Ilmiah Keagamaan dan Kemasyarakatan Vol. 16, No. 1

Januari - Juni 2022 
Dewasa ini, dibutuhkan sosok pemimpin yang mampu memimpin dan menjadi teladan bagi bawahannya untuk bersama melakukan perubahan ke arah positif. Kepemimpinan merupakan suatu hal yang dinamis, berubah, dan berkembang sesuai masanya sehingga banyak konsep gaya kepemimpinan yang berkembang.

Kepemimpinan adalah rangkaian kegiatan penataan berupa kemampuan mempengaruhi perilaku orang lain dalam situasi tertentu agar bersedia bekerjasama untuk mencapai tujuan yang ditetapkan. Dalam menjalankan kepemimpinannya, seorang pemimpin memiliki gaya-gaya tersendiri. Gaya (style) adalah suatu cara berperilaku yang khas dari seorang pemimpin terhadap para anggota kelompoknya. Kepemimpinan (leadership) adalah kemampuan yang harus dimiliki oleh seorang pemimpin (leader) tentang bagaimana menjalankan kepemimpinannya (to lead) sehingga bawahan dapat bergerak sesuai dengan yang diinginkan dalam mencapai tujuan yang ditetapkan sebelumnya.

Di zaman yang modern ini, kepemimpinan masih dianggap sebagai kekuatan utama dalam rangka merubah tatanan kebangsaan. Sesuai dengan visi dan misinya, misi abadi kepemimpinan adalah "pencerahan kehidupan bangsa" yang ditempuh melalui proses perubahan yang lebih objektif dalam pertautan zaman glamor ini.

Di Indonesia pada umumnya kekuasaan pemimpin dalam konteks personal power itu tidak akan berarti apa-apa untuk dapat menjelaskan bahwa kepemimpinan yang dijalankan efektif dalam mempengaruhi orang lain. Akan tetapi dibutuhkan personal behavior pemimpin dan keterampilan yang dijalankan efektif dalam mempengaruhi harus terangkum didalamnya bila kita menginginkan kelanjutan bagaimana pemimpin memengaruhi orang lain.

Kepemimpinan dalam konteks pendidikan makro dalam menyikapi tantangan globalisasi yang ditandai dengan adanya kompetisi global yang sangat ketat dan tajam, di beberapa negara telah berupaya untuk melakukan revitalisasi pendidikan. Revitalisasi ini termasuk pula dalam hal perubahan paradigma kepemimpinan pendidikan, terutama dalam hal pola hubungan atasanbawahan, yang semula bersifat hierarkis-komando menuju ke arah kemitraan bersama. Pada hubungan atasan-bawahan yang bersifat hierarkis komando, seringkali menempatkan bawahan sebagai objek tanpa daya. Pemaksaan kehendak dan pragmatis merupakan sikap dan perilaku yang kerap kali mewarnai kepemimpinan komandobirokratik-hierarkis, yang pada akhirnya hal ini berakibat fatal terhadap terbelenggunya sikap inovatif dan kreatif dari setiap bawahan. Dalam melaksanakan tugas dan kewajiban, mereka cenderung bersikap a priori dan bertindak hanya atas dasar perintah sang pemimpin semata. Dengan kondisi demikian, pada akhirnya akan sulit dicapai kinerja yang unggul.

Masalah kepemimpinan telah muncul bersamaan dengan dimulainya sejarah manusia, yaitu sejak manusia menyadari pentingnya hidup berkelompok untuk mencapai tujuan bersama. Mereka

Al Qalam: Jurnal Ilmiah Keagamaan dan Kemasyarakatan Vol. 16, No. 1

Januari - Juni 2022 
membutuhkan seseorang atau beberapa orang yang mempunyai kelebihan-kelebihan daripada yang lain, terlepas dalam bentuk apa kelompok manusia tersebut dibentuk. Hal ini tidak dapat dipungkiri karena manusia selalu mempunyai keterbatasan dan kelebihan-kelebihan tertentu.

Organisasi yang berhasil dalam mencapai tujuannya serta mampu memenuhi tanggung jawab sosialnya akan sangat tergantung pada para manajernya (pimpinannya). Apabila manajer mampu melaksanakan fungsi-fungsinya dengan baik, sangat mungkin organisasi tersebut akan dapat mencapai sasarannya. Suatu organisasi membutuhkan pemimpin yang efektif, yang mempunyai kemampuan mempengaruhi perilaku anggotanya atau anak buahnya. Jadi, seorang pemimpin atau kepala suatu organisasi akan diakui sebagai seorang pemimpin apabila ia dapat mempunyai pengaruh dan mampu mengarahkan bawahannya ke arah pencapaian tujuan organisasi.

Ada suatu pendekatan yang dapat digunakan untuk memahami kesuksesan dari kepemimpinan, yakni dengan memusatkan perhatian pada apa yang dilakukan oleh pemimpin tersebut. Jadi yang dimaksudkan disini adalah gayanya. Gaya kepemimpinan merupakan norma perilaku yang digunakan oleh seseorang pada saat orang tersebut mencoba mempengaruhi perilaku orang lain seperti yang ia inginkan. Gaya kepemimpinan dalam organisasi sangat diperlukan untuk mengembangkan lingkungan kerja yang kondusif dan membangun iklim motivasi bagi karyawan sehingga diharapkan akan menghasilkan produktivitas yang tinggi.

Dibutuhkan pemimpin pendidikan Indonesia di era milenium yang memiliki jiwa kepemimpinan seutuhnya yaitu orang yang mempunyai kemampuan untuk mempengaruhi, mengarahkan, membimbing dan juga sebagian orang yang mempunyai kegiatan untuk mempengaruhi perilaku orang lain agar mengikuti apa yang menjadi kehendak dari pada atasan atau pimpinan mereka sehingga terbentuk kerjasama di dalam kelompok untuk mencapai tujuan organisasi dengan sadar, rela, dan sepenuh hati dengan gaya kepemimpinan yang khas.

Pemimpin pendidikan ini harus mampu menghadapi globalisasi. Dalam menuju era globalisasi, pemimpin pendidikan Indonesia harus mampu melakukan reformasi dalam proses pendidikan, dengan tekanan menciptakan sistem pendidikan yang lebih komprehensif dan fleksibel. Demokratisasi pendidikan harus dijadikan suatu paradigma baru dalam memperkukuh sistem pendidikan Indonesia karena memberikan ruang yang lebih besar kepada lembaga penyelenggara pendidikan dan masyarakat untuk berperan dengan lebih nyata. Di samping itu, pemimpin pendidikan tersebut harus mampu mengelola aspek-aspek kelembagaan, kurikulum, sumber daya manusia, pembiayaan, dan sarana prasarana dimana implementasi dari kebijakan tersebut perlu disesuaikan dengan kondisi daerah.

Pemimpin pendidikan Indonesia harus mampu mengemas sistem pendidikan nasional berorientasi agar berorientasi pada pembangunan jiwa, harus berani mengambil kebijakan memajukan dunia pendidikan dan membuat alokasi dana pendidikan dana yang lebih besar di sektor

Al Qalam: Jurnal Ilmiah Keagamaan dan Kemasyarakatan Vol. 16, No. 1

Januari - Juni 2022 
pendidikan sebagai bagian investasi jangka panjang demi kepentingan masa depan bangsa. Kebijakan pendidikan nasional harus lebih pragmatis, kreatif, dan segera. ${ }^{1}$

Dari uraian di atas dapat dirumuskan permasalahan dalam makalah ini, yaitu: Bagaimana Model kepemimpinan pendidikan masa depan berbasis agama, filsafat, psikologi, dan sosiologi. Tujuan dari penulisan makalah ini adalah untuk mengetahuii, menganalisis dan mendapatkan informasi model kepemimpinan pendidikan masa depan berbasis agama, filsafat, psikologi, dan sosiologi.

\section{METODE PENELITIAN}

Penelitian ini merupakan penelitian library research yang dalam pengumpulan datanya peneliti mengumpulkan ragam literatur dari berbagai disiplin ilmu sehingga bisa memberikan pandangan luas terkait pendidikan. Data yang sudah dikumpulkan kemudian dianalisis menggunakan content analysis sebagai pisau analisisnya sehingga ditemukan ragam pandangan yang bisa saling melengkapi antar disiplin ilmu yang ingin digali oleh peneliti.

\section{HASIL DAN PEMBAHASAN}

\section{Model Kepemimpinan Berbasis Agama}

Seringkali kita mendengar istilah kepemimpinan bahkan banyak pakar yang telah mengemukakan definisi kepemimpinan, tetapi tidak ada satu pun definisi yang diterima dengan pasti. Kepemimpinan dapat diartikan sebagai proses dan sebagai sifat-sifat yang dimiliki. ${ }^{2}$

Di sisi lain, banyaknya studi yang dilakukan tentang kepemimpinan, dan hasilnya adalah berupa rumusan, konsep, dan teori kepemimpinan. Studi dan rumusan kepemimpinan yang dihasilkan sangat dipengaruhi oleh paradigma dan pendekatan yang digunakan sehingga teori-teori yang di hasilkan mempunyai perbedaan dalam hal metodologi, pendapat dan uraiannya, penafsiran dan kesimpulannya. Dengan demikian rumusan yang perlu dihasilkan akan mengarah pada suatu teori konsep yang benarbenar memiliki kualitas terhadap eksistensi kepemimpinan yang ada dalam dunia pendidikan. Membincang pemimpin, berarti berbicara diri sendiri. ${ }^{3}$

Dalam pandangan Amrozi, ${ }^{4}$

diri adalah entitas atau wujud otonom yang diciptakan Allah dalam dua demensi. ada demensi raga dan demensi jiwa (jasmani dan rohani). Dari dua unsur tersebut manusia telah menjadi pemimpin bagi dirinya sendiri. Jiwa akan menjadi pemimpin bagi jasadnya, sebab jiwa adalah suatu penggerak atau daya dari pada raga.

\footnotetext{
${ }^{1}$ Meilani Hartono, "Kepemimpinan Pendidikan Indonesia pada Era Milenium," Diterima dari https://pgsd. binus. ac. id/2018/11/23/kepemimpinan-pendidikan-indonesia-pada-era-milenium, 2018.

${ }^{2}$ Alo Liliweri, Wacana Komunikasi Organisasi (Bandung: Mandar Maju, 2004), h. 151.

${ }^{3}$ Ara Hidayat dan Imam Machali, Pengelolaan Pendidikan: Konsep, Prinsip, dan Aplikasi dalam Mengelola Sekolah dan Madrasah (Jakarta: Pustaka Educa, 2012), h. 86.

${ }^{4}$ Shoni Rahmatullah Amrozi, Menggagas Pemimpin Masa Depan (Jember: Pena Salsabila, 2010), h. 4.
}

Al Qalam: Jurnal Ilmiah Keagamaan dan Kemasyarakatan Vol. 16, No. 1 Januari - Juni 2022 
Jiwa akan memberi komando pada raga. Di dalam jiwa terdapat banyak potensi-potensi ilahiyah yang akan mengantarkan manusia pada kepemimpinan pada dirinya, sedangkan jasad adalah organ yang terdiri dari bagian-bagian tertentu. Dari masing-masing organ tersebut akan bekerja sesuai dengan tugasnya masing-masing, mata akan bekerja untuk melihat, telinga untuk mendengar, mulut untuk berbicara dan banyak fungsi fungsi dari organ lainnya.

Dengan demikian kepemimpinan mencakup distribusi kekuasaan yang tidak sama di antara pemimpin dan anggotanya. Pemimpin mempunyai wewenang untuk mengarahkan anggota dan juga dapat memberikan pengaruh, dengan kata lain para pemimpin tidak hanya dapat memerintah bawahan apa yang harus dilakukan, tetapi juga dapat memengnaruhi bagaimana bawahan melaksanakan perintahnya. Sehingga terjalin suatu hubungan sosial yang saling berinteraksi antara pemimpin dengan bawahan, yang akhirnya tejadi suatu hubungan timbal balik.

Oleh sebab itu, bahwa pemimpin diharapakan memiliki kemampuan dalam menjalankan kepemimpinannya, kareana apabila tidak memiliki kemampuan untuk memimpin, maka tujuan yang ingin dicapai tidak akan dapat tercapai secara maksimal. Sehubungan dengan itu kalau kita rangkaikan dengan pengertian kepemimpinan diatas berarti kepemimpinan pendidikan adalah kemampuan yang dimiliki oleh seseorang dalam proses mempengaruhi, mendorong, membimbing, dan menggerakkan orang lain yang ada hubungannya dengan pelaksanaan dan pengembangan pendidikan dan pengajaran, agar segenap kegiatan dapat berjalan secara efektif dan efesien yang pada gilirannya dapat mencapai tujuan pendidikan dan pengajaran yang telah ditetapkan. Dengan ringkas dapat diungkapkan sebagai bantuan yang di berikan oleh seseorang tehadap penetapan dan pencaian tujuan pendidikan dan pengajaran.

Lembaga pendidikan membutuhkan seorang pemimpin. Sebab, pemimpin itulah sosok penggerak dan inspirasi dalam merancang dan mengerjakan kegiatan. Pemimpin dalam pendidikan tidak hanya seorang manajer, ia juga harus seorang pembangun mental, moral, spirit, dan kolektivitas kepada jajaran bawahannya. Seorang pemimpin sayogianya tidak hanya menggunakan aturan tertulis, tapi juga sikap prilaku, sepak terjang dan keteladanan dalam melakukan agenda transformasi kearah yang lebih baik. ${ }^{5}$

Berikut ini beberapa teori kepemimpinan. Pertama, teori otokratis dan pemimpin otokratis. Pemimpin otokratis cendrung disebut otokrat keras. Pada intinya teori otokrat ini memiliki sifatsifat yang tepat, seksama, sesuai dengan prinsip, namun keras dan kaku. Pemimpin tidak akan pernah mendelegasikan otoritasnya. Lembaga atau organisasi yang dipimpinnya merupakan a oneman show. Karena dengan keras ia menekankan prinsip-prinsip Business is business atau dengan

5 Jamal Ma'mur Asmani, Manajemen Pengelolaan dan Kepemimpinan Pendidikan Profesional: Panduan Quality Control bagi Para Pelaku Lembaga Pendidikan (Jogjakarta: DIVA Press, 2009), h. 91.

Al Qalam: Jurnal Ilmiah Keagamaan dan Kemasyarakatan Vol. 16, No. 1

Januari - Juni 2022 
kata lain waktu adalah uang untuk bias makan, orang harus kerja keras, dan kecenderungan teori ini mengejar sesuatu kemenangan yang mutlak. Sikap dan prinsipnya sangat konservatif. Pemimpinnya akan bersikap baik terhadap orang-orang yang patuh serta loyal dan sebaliknya, disatu sisi dia akan bertindak keras dan sangat kejam terhadap bawahannya yang membangkan perintahnya. ${ }^{6}$

Kedua, teori psikologis. Teori ini menyatakan bahwa fungsi seorang pemimpin adalah memunculkan dan mengambangkan system motivasi terbaik, untuk merangsang bawahan agar mereka mau bekerja, guna untuk mencapai sasaran-sasaran organisatoris dan untuk memenuhi tujuan-tujuan pribadi. Oleh karena itu, pemimpin yang mampu memotivasi orang lain akan sangat mementingkan aspek-aspek psikis manusia, seperti pengakuan (recognizing), martabat, status social, kepastian emosional, memperhatikan keinginan dan kebutuhan pegawai, kegairahan kerja, minat, suasana, dan hati.

Ketiga, teori sosiologis. Dalam teori ini, kepemimpinan dianggap sebagai usaha- usaha untuk melancarkan antar-relasi dalam organisasi atau lembaga, dan sebagai usaha untuk menyelesaikan setiap konflik organisatoris antara para pengikutnya. Agar tercapai kerja sama yang baik, pemimpin menetapkan tujuantujuan, dengan meyertakan para pengikut dalam pengambilan keputusan terakhir. Selanjutnya juga mengidentifikasi tujuan, dan kerap kali memberikan petunjuk yang diperlukan bagi para pengikut untuk melakukan setiap tindakan yang berkaitan dengan kepentingan kelompoknya. ${ }^{7}$

Studi tentang kepemimpinan dari waktu kewaktu menunjukkan bahwa pemimpin yang paling sukses untuk melakukan perubahan adalah mereka yang telah berusaha menerapkan kepemimpinan transformatif atau transformasional. Mereka sukses dalam meningkat komitmen pengikutnya untuk melaksanakan tugas kelembagaan sehingga mereka benar-benar memiliki kewajiban moral. Maka dari itu, kapasitas kepemimpinan ini perlu dikembangkan di dunia pesantren khususnya pada transisi menuju kepada sistem pengelolahan pondok pesantren yang efektif.

Kepemimpinan (leadership) adalah proses mempengaruhi yang dilakukan oleh seseorang terhadap orang lain untuk dapat bekerja sama dalam mencapai tujuan atau sasaran bersama yang telah ditetapkan. Menurut Alquran QS Al-Ahzab:21:

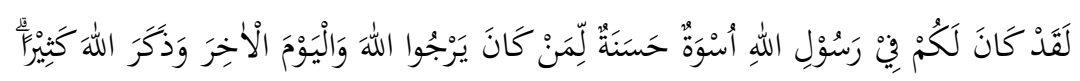

Artinya: Sungguh, telah ada pada (diri) Rasulullah itu suri teladan yang baik bagimu (yaitu) bagi orang yang mengharap (rahmat) Allah dan (kedatangan) hari Kiamat dan yang banyak mengingat Allah.

${ }^{6}$ Hidayat dan Machali, Pengelolaan Pendidikan: Konsep, Prinsip, dan Aplikasi dalam Mengelola Sekolah dan Madrasah, h. 86.

${ }^{7}$ Hidayat dan Machali, h. 87.

Al Qalam: Jurnal Ilmiah Keagamaan dan Kemasyarakatan Vol. 16, No. 1

Januari - Juni 2022 
Pertama, tidak mengambil orang kafir atau orang yang tidak beriman sebagai pemimpin bagi orang-orang muslim karena bagaimanapun akan mempengaruhi kualitas keberagamaan rakyat yang dipimpinnya, sebagaimana firman Allah dalam Alquran; Surat An-Nisaa: 144.

Kedua, tidak mengangkat pemimpin dari orang-orang yang mempermainkan Agama Islam, sebagaimana firman Allah dalam Surat Al-Maidah: 57.

Ketiga, pemimpin harus mempunyai keahlian di bidangnya, pemberian tugas atau wewenang kepada yang tidak berkompeten akan mengakibatkan rusaknya pekerjaan bahkan organisasi yang menaunginya. Sebagaimana Sabda Rasulullah SAW. "Apabila suatu urusan diserahkan kepada yang bukan ahlinya, maka tunggulah masa kehancurannya”. (HR Bukhori dan Muslim).

Keempat, pemimpin harus bisa diterima (acceptable), mencintai dan dicintai umatnya, mendoakan dan didoakan oleh umatnya. Sebagaimana Sabda Rasulullah saw. "Sebaik-baiknya pemimpin adalah mereka yang kamu cintai dan mencintai kamu, kamu berdoa untuk mereka dan mereka berdoa untuk kamu. Seburuk-buruk pemimpin adalah mereka yang kamu benci dan mereka membenci kamu, kamu melaknati mereka dan mereka melaknati kamu." (HR Muslim).

Kelima, pemimpin harus mengutamakan, membela dan mendahulukan kepentingan umat, menegakkan keadilan, melaksanakan syari'at, berjuang menghilangkan segala bentuk kemunkaran, kekufuran, kekacauan, dan fitnah, sebagaimana Firman Allah SWT. Dalam Alquran, Surat AlMaidah: 8. Keenam, pemimpin harus memiliki bayangan sifat-sifat Allah swt yang terkumpul dalam Asmaul Husna dan sifat-sifat Rasul-rasul-Nya.

Karakter yang harus dimiliki dalam sebuah kepemimpinan adalah: Pertama, Shidiq (jujur). Seorang pemimpin wajib berlaku jujur dalam melaksanakan tugasnya. Jujur dalam arti luas. Tidak berbohong, tidak menipu, tidak mengada-ngada fakta, tidak bekhianat, serta tidak pernah ingkar janji dan lain sebagainya. Mengapa harus jujur? Karena berbagai tindakan tidak jujur selain merupakan perbuatan yang jelas-jelas berdosa, jika biasa dilakukan, juga akan mewarnai dan berpengaruh negatif kepada kehidupan pribadi dan keluarga pemimpin itu sendiri. Bahkan lebih jauh lagi, sikap dan tindakan yang seperti itu akan mewarnai dan mempengaruhi kehidupan bermasyarakat.

Dalam Alquran, keharusan bersikap jujur dalam memimpin, sudah diterangkan dengan sangat jelas dan tegas yang antara lain kejujuran tersebut. Di beberapa ayat, dihuhungkan dengan pelaksanaan timbangan:

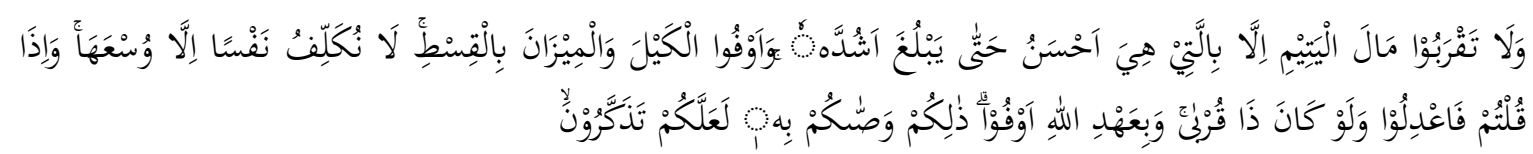

Dan janganlah kamu mendekati harta anak yatim, kecuali dengan cara yang lebih bermanfaat,

Al Qalam: Jurnal Ilmiah Keagamaan dan Kemasyarakatan Vol. 16, No. 1

Januari - Juni 2022 
sampai dia mencapai (usia) dewasa. Dan sempurnakanlah takaran dan timbangan dengan adil. Kami tidak membebani seseorang melainkan menurut kesanggupannya. Apabila kamu berbicara, bicaralah sejujurnya, sekalipun dia kerabat(mu) dan penuhilah janji Allah. Demikianlah Dia memerintahkan kepadamu agar kamu ingat." (Q.S. Al Ahzab:152)

Dengan hanya menyimak ayat tersebut di atas, maka kita sudah dapat mengambil kesimpulan bahwa; sesungguhnya Allah swt telah menganjurkan kepada seluruh umat manusia pada umumnya, dan kepada para pedagang khususnya untuk berlaku jujur dalam menimbang, menakar dan mengukur barang dagangan. Penyimpangan dalam menimbang, menakar dan mengukur yang merupakan wujud kecurangan dalam perdagangan, sekalipun tidak begitu nampak kerugian dan kerusakan yang diakibatkannya pada manusia ketimbang tindak kejahatan yang lebih besar lagi seperti; perampokan, perampasan, pencurian, korupsi, manipulasi, pemalsuan dan yang lainnya, nyatanya tetap diharamkan oleh Allah swt dan Rasul-Nya. Mengapa? Jawabnya adalah; karena kebiasaan melakukan kecurangan menimbang, menakar dan mengukur dalam dunia perdagangan, akan menjadi cikal bakal dari bentuk kejahatan lain yang jauh lebih besar.

Sebagai pemimpin hendaknya kita selalu berupaya menyempurnakan keilmuan, berani mengambil risiko dan mampu mengambil ibrah dari keberhasilan serta kegagalan para pemimpin terdahulu. Jadilah pemimpin yang berangkat atas dasar keilmuan dan ketakwaan bukan atas dasar nafsu dan keserakahan.

\section{Model Kepemipinan Berbasis Filsafat}

Permasalahan yang terjadi yakni maraknya praktik kepemimpinan sekarang ini yang mengadopsi model kepemimpinan dari luar, seperti Eropa, Amerika Serikat, maupun Jepang sehingga perlu adanya reinterpretasi dan adaptasi agar relevan dengan kebudayaan lokal. Karena kepemimpinan merupakan bentuk kebudayaan dalam tatanan masyarakat maupun lembaga pendidikan. Kebudayaan merupakan keseluruhan gagasan, tindakan maupun hasil karya manusia. Kepemimpinan memiliki warna tersendiri dalam kebudayaan, karena kebudayaan adalah proses interaksi antar manusia. Interaksi dalam hal ini dipenuhi dengan orientasi dan nilai-nilai yang diharapkan oleh pemimpin. ${ }^{8}$

Tanah Air Indonesia sekarang ini nampaknya cenderung meniru gaya kepemimpinan Eropa dan Amerika Serikat. Sedangkan gaya kepemimpinan yang diwariskan leluhur sendiri (raja, tokoh masyarakat, tokoh agama, satrawan, dll) sudah banyak yang mengabaikan dan melupakan. Sesungguhnya ajaran yang diwariskan leluhur tersebut memiliki ajaran yang bermoral, yang dapat membentuk watak dan kepribadian pemimpin jika dikaji dan diterapkan kembali. ${ }^{9}$

\footnotetext{
${ }^{8}$ Suwardi Endraswara, Falsafah Kepemimpinan Jawa: Butir-Butir Nilai yang Membangun Karakter Seorang Pemimpin Menurut Budaya Jawa (Yogyakarta: Narasi, 2013), h. 2.

${ }^{9}$ Kartini Kartono, Pemimpin dan Kepemimpinan: Apakah Kepemimpinan Abnormal Itu? (Jakarta: Rajawali Pers, 2014), h. 4.
}

Al Qalam: Jurnal Ilmiah Keagamaan dan Kemasyarakatan Vol. 16, No. 1

Januari - Juni 2022 
Diumpakan mutiara yang terkubur dalam oleh peradaban dan perkembangan masa, penggunaan teori-teori dari luar nampaknya semakin menenggelamkan eksistensi falsafah Jawa. Penggalian falasafah kepemimpinan Jawa merupakan upaya untuk mengangkat kembali pijakan kuat bagi seorang pemimpin. Bisa jadi pemimpin yang ada saat ini telah melompat terlalu jauh dari pijakan esensinya. Tak jarang karena hal inilah, seluruh lapisan dalam lembaga pendidikan cenderung lebih apatis terhadap sosok pemimpin yang seharusnya dapat dijadikan teladan.

Dalam organisasi seperti lembaga pendidikan, kepemimpinan merupakan salah satu unsur penting yang menentukan kelangsungan hidup lembaga pendidikan tersebut. Keberhasilan lembaga pendidikan sebagai penyelenggara pendidikan terletak pada kemampuan pemimpinnya dalam mengembangkan visi, model serta gaya atau pola kepemimpinannya. Jatuh bangunnya sebuah organisasi tergantung kepada pemimpinnya. Oleh karena itu kepemimpinan menjadi pusat perhatian manusia. Kepemimpinan sangat dibutuhkan, karena adanya suatu keterbatasan dan kelebihan-kelebihan tertentu pada manusia. Di satu pihak manusia terbatas kemampuannya untuk memimpin, di pihak lain ada orang yang mempunyai kelebihan kemampuan untuk memimpin. Di sinilah timbulnya kebutuhan akan pemimpin dan kepemimpinan.

Bagi seorang pemimpin pendidikan penting sekali untuk mempunyai landasan filsafat dalam bertindak. Filsafat adalah pandangan hidup seseorang atau sekelompok orang yang merupakan konsep dasar mengenai kehidupan yang dicita-citakan. Filsafat juga diartikan sebagai suatu sikap seseorang yang sadar dan dewasa dalam memikirkan segala sesuatu secara mendalam dan ingin melihat dari segi yang luas dan menyeluruh dengan segala hubungan. Filsafat memegang peranan penting dalam kehidupan diantaranya, adalah: ${ }^{10}$

a. Sebagai dasar dalam bertindak

b. Sebagai dasar dalam mengambil keputusan

c. Untuk mengurangi salah paham dan konflik

d. Untuk bersiap siaga menghadapi situasi dunia yang selalu berubah.

Adapun beberapa aliran-aliran filsafat Pendidikan adalah: ${ }^{11}$

1) Progresivisme

Aliran ini berpendapat bahwa pengetahuan yang benar pada masa kini mungkin tidak benar dimasa mendatang. Dimana pendidikan harus berpusat pada anak dan bukan memfokuskan pada guru atau bidang muatan.

2) Esensialisme

Esensialisme adalah pendidikan yang didasarkan kepada nilai-nilai kebudayaan yang telah ada

\footnotetext{
${ }^{10}$ Fauziyah Mastuti dan Tukiman Taruno, "Pola Kepemimpinan Organisasi Pendidikan di Jawa Tengah Ditinjau dari Filsafat Pendidikan Menurut Kaplan,” 2009.

${ }^{11}$ NMY Anita, I W Karyasa, dan I Nyoman Tika, Filsafat Ilmu (Singaraja: Undiksha Press, 2013).
}

Al Qalam: Jurnal Ilmiah Keagamaan dan Kemasyarakatan Vol. 16, No. 1

Januari - Juni 2022 
sejak awal peradaban umat manusia.

3) Perenialisme

Pandangan perenialis menyatakan bahwa pendidikan harus lebih banyak mengarahkan pusat perhatiannya pada kebudayaan ideal yang telah teruji dan tangguh. Perenialisme memandang pendidikan sebagai jalan kembali atau proses mengembalikan keadaan manusia sekarang seperti dalam kebudayaan ideal.

4) Rekonstruksionisme

Dalam konteks filsafat pendidikan, aliran rekonstruksionisme adalah suatu aliran yang berusaha merombak tata susunan lama dan membangun tata susunan hidup kebudayaan yang bercorak modern.

Sedangkan Kaplan, mengklasifikasikan filsafat menjadi empat, yaitu: ${ }^{12}$

a) Rasionalisme

Pemikiran filsafat rasionalisme memberikan peranan yang sangat penting kepada kemampuan akal budi (rasio) manusia. Akal budi manusia merupakan sumber ilmu peengetahuan dan sumber nilai termasuk sumber-sumber nilai moral. Pemikiran pendidikan yang sejalan dengan rasionalisme adalah mengembangkan akal manusia untuk menguasai dunia, perkembangan dirinya, penguasaan alam, bahkan destinasi kehidupannya.

b) Humanisme

Pemikiran filsafat humanisme bertolak dari pengakuan terhadap manusia. Manusia adalah individu yang rasional sebagai nilai tertinggi dan sumber nilai yang terakhir. Manusia dianggap bukan bagian dari alam yang statis tetapi sebagai makhluk yang kreatif. Humanisme melihat alam dan dunia sebagai dunia yang terbuka dan kebebasan manusia untuk menyusun dan mengaturnya. Kebebasan indivdu dan tanggung jawab serta melihat dunia yang memberikan berbagai pilihan, telah mendorong manusia itu sebagai makhluk yang harus memikul tanggung jawab atas kebebasannya.

c) Aktivisme

Dala aktivisme hubungan manusia dan dunia sebagai subyek yang mengerti dan memberi makna pada alam sebagai obyek. Pemikiran ini juga menempatkan manusia sebagai makhluk yang mempunyai kemampuan menyusun obyek-obyek atau dunia. Yang terpenting dalam filsafat aktivisme ialah instrument dan bukan tujuan. Tidak ada tujuan akhir, karena semuanya terus berubah sesuai dengan aktivisme yang dikembangkan oleh individu.

d) Filsafat Nilai

Filsafat ini mengakui bahwa yang abadi adalah nilai-nilai dan bukan sesuatu yang kelihatan.

${ }^{12}$ Mastuti dan Taruno, "Pola Kepemimpinan Organisasi Pendidikan di Jawa Tengah Ditinjau dari Filsafat Pendidikan Menurut Kaplan.”

Al Qalam: Jurnal Ilmiah Keagamaan dan Kemasyarakatan Vol. 16, No. 1

Januari - Juni 2022 
Kehidupan manusia adalah perwujudan dari nilai-nilai yang abadi. Dalam filsafat nilai yang terpenting adalah esensi dari kehidupan manusia.

Dari keempat filsafat ini penting untuk dipahami oleh setiap pemimpin dalam bertindak. Pemimpin harus paham bahwa manusia adalah makhluk yang rasionalis, humanis, aktif dan berorientasi pada nilai. Ditinjau dari kriteria kepemimpinan pendidikan yang telah disebutkan diatas, dapat disimpulkan bahwa jika seorang pemimpin pendidikan menghadapi setiap persoalan yang ada maka pemimpin dapat menggunakan pendekatan rasionalisme dan humanisme.

Dimana pendekatan rasionalis berfungsi untuk menentukan dalam pengambilan kebijakan. Sedangkan pendekatan humanis berfungsi untuk membangun hubungan yang baik antara sesame rekan kerja.

\section{Model Kepemipinan Berbasis Psikologis}

Meskipun istilah modal psikologis telah dibanyak disebutkan dalam berbagai penelitian ekonomi dan sosiologi, para ahli psikologi memiliki definisi yang berbeda. Secara khusus, para ahli psikologi berfokus pada kekuatan yang ada dalam diri individu, bukan kelemahan, kesehatan dan vitalitas daripada penyakit dan patologi. Istilah modal psikologis pertama kali muncul dalam buku yang berjudul Authentic Happiness karangan Martin Selligman. ${ }^{13}$

Kemudian Luthans et al, mendefinisikan modal psikologis Yaitu: ${ }^{14}$

"An individual"s positive psychological state of development that is characterized by: (1) having confidence (Self-efficacy) to take on and put in the necessary effort to succeed at challenging tasks; (2) making a positive attribution (optimism) about succeeding now and in the future; (3) persevering toward goals, and when necessary redirecting paths to goals (Harapan) in order to succeed; and (4) when beset by problems and adversity, sustaining and bouncing back and even beyond (resilience) to attain success."

Dari definisi ini, kita dapat melihat bahwa modal psikologis terdiri dari 4 dimensi (Selfefficacy, optimisme, harapan dan ketahanan) yang satu dengan yang lain memiliki benang merah dari kecenderungan motivasi untuk mencapai tujuan dan sukses. Secara keseluruhan, modal psikologis telah dibuktikan secara konseptual dan secara empiris dapat memprediksi hasil kerja yang diinginkan seperti kinerja dan kepuasan kerja.

Sementara itu Luthan et al. mendefinisikan Self-efficacy sebagai keyakinan individu tentang kemampuannya untuk memobilisasi motivasi, sumber daya kognitif, dan tindakan yang diperlukan untuk berhasil melaksanakan suatu tugas dalam konteks tertentu. ${ }^{15}$ Optimisme, Luthans et al. mendefinisikan optimisme sebagai model pemikiran yang memungkinkan individu

13 Anita Yuniarti dan Desi Yustari Muchtar, "Pengaruh Modal Psikologis Dan Persepsi Gayakepemimpinan Transformasional Terhadap Workplace Well Being," TAZKIYA: Journal of Psychology 4, no. 2 (2019): h. 287.

14 Yuniarti dan Muchtar, h. 187.

15 Fred Luthans dkk., "The Development And Resulting Performance Impact Of Positive Psychological Capital," Human resource development quarterly 21, no. 1 (2010): 41-67.

Al Qalam: Jurnal Ilmiah Keagamaan dan Kemasyarakatan Vol. 16, No. 1

Januari - Juni 2022 
mengatribusikan kejadian positif ke dalam diri sendiri, bersifat permanen, di lain hal menginterpretasikan kejadian negatif kepada aspek eksternal, bersifat sementara atau temporer, dan merupakan faktor yang disebabkan oleh situasi tertentu. Pengertian optimis menggambarkan keyakinan bahwa sesuatu yang baik akan diperoleh. Dalam dunia kerja, optimisme ini juga berhubungan secara positif kepada hal yang memuaskan seperti workplace performance dan performa di berbagai aspek kehidupan seperti pendidikan, olahraga dan politik. Sedangkan, untuk hal negatif yang dapat dihasilkannya adalah seperti depresi, penyakit fisik dan rendahnya performa di setiap bidang kehidupan. ${ }^{16}$ Optimisme sebagai segi modal psikologis dikaitkan dengan pandangan positif realistis tetapi bukan proses yang tanpa evaluasi. Harapan, Snyder et al. mendefinisikan harapan sebagai kodisi motivasi positif yang didasari oleh interaksi akan perasaan sukses (1) agency (goal-directed energy) dan (2) pathways (planning to meet goals). Dengan kata lain, harapan terdiri dari dua point penting, yaitu; agency/wiilpower yang merupakan determinasi untuk mencapai tujuan; dan waypower yang merupakan rencana alternatif hasil pemikiran seseorang untuk mencapai tujuannya.

Dalam berbagai penelitian, harapan ditemukan berpengaruh positif terhadap kinerja yang lebih baik. Ketahanan, Ketahanan didefinisikan sebagai kapasitas psikologis seseorang yang bersifat positif, dengan menghindarkan diri dari ketidakbaikan, ketidakpastian, konflik, kegagalan, sehingga dapat menciptakan perubahan positif, kemajuan dan peningkatan tanggung jawab. Berbeda dengan self-efficacy, optimisme, dan harapan yang lebih bersifat proaktif, ketahanan dari seseorang lebih bersifat reaktif, yang terjadi ketika seseorang berhadapan dengan perubahan, ketidakbaikan, atau ketidakpastian. ${ }^{17}$

\section{Model Kepemipinan Berbasis Sosiologis}

Pemimpin pada hakikatnya adalah seseorang yang mempunyai kemampuan untuk mempengaruhi perilaku orang lain di dalam kerjanya dengan menggunakan kekuasaan. Kekuasaan adalah kemampuan untuk mengarahkan dan mempengaruhi bawahan sehubungan dengan tugastugas yang harus dilaksanakan. Menurut Stone, semakin banyak jumlah sumber kekuasaan yang tersedia bagi pemimpin, akan makin besar potensi kepemimpinan yang efektif. Jenis pemimpin ini bermacam-macam, ada pemimpin formal, yaitu yang terjadi karena pemimpin bersandar pada wewenang formal. Ada pula pemimpin nonformal, yaitu terjadi karena pemimpin tanpa wewenang formal berhasil mempengaruhi perilaku orang lain. ${ }^{18}$

Sehubungan dengan itu menurut Wahjosumidjo, menyatakan Kepemimpinan memiliki

\footnotetext{
${ }^{16}$ Fred Luthans dkk., "Positive Psychological Capital: Measurement and Relationship With Performance and Satisfaction," Personnel psychology 60, no. 3 (2007): 541-72.

${ }^{17}$ Luthans dkk.

${ }^{18}$ Syukur Fatah, Psikologi Pendidikan dengan Pendekatan Baru (Semarang: Rasail, 2008), h. 88.
}

Al Qalam: Jurnal Ilmiah Keagamaan dan Kemasyarakatan Vol. 16, No. 1

Januari - Juni 2022 
beberapa implikasi, antara lain: ${ }^{19}$

a. Kepemimpinan berarti melibatkan orang atau pihak lain, yaitu para karyawan atau bawahan (fllowers). Para karyawan atau bawahan harus memiliki kemauan untuk menerima arahan dari pemimpin. Walaupun demikian, tanpa adanya karyawan, tidak akan ada pemimpin.

b. Seorang pemimpin yang efektif adalah seseorang yang dengan kekuasaannya (his or herpower) mampu menggugah pengikutnya untuk mencapai kinerja yang memuaskan. Para pemimpin dapat menggunakan bentuk-bentuk kekuasaan atau kekuatan yeng berbeda untuk mempengaruhi perilaku bawahan dalam berbagai situasi.

c. Kepemimpinan harus memiliki kejujuran terhadap diri sendiri (integrity), sikap bertanggung jawab yang tulus (compassion), pengetahuan (cignizance), keberanian bertindak dengan keyakinan (commitment), kepercayaan pada diri sendiri dan orang lain (confidence) dan kemampuan untuk meyakinkan orang lain (comminication) dalam mambangun organisasi.

Secara sosiologis, berikut tugas pokok seorang pemimpin:

1) Memberikan suatu kerangka pokok yang jelas.

Dimana kerangka pokok itu dapat dijadikan pegangan bagi masyarakat. Dengan adanya kerangka pokok tersebut, maka dapat disusun suatu skala prioritas mengenai keputusan-keputusan yang perlu diambil untuk menanggulangi masalah-masalah yang dihadapi (yang sifatnya potensial atau nyata). Visi dan Misi yang menjadi pegangan seorang pemimpin. Jika visi dan misi ini sesuai dengan kerangka pokok, serta ide atau gagasan yang Ia punya, maka akan berjalan sebagaimana mestinya. Dan tidak hanya tim sukses saja yang menjalankan visi dan misi tersebut.

2) Mengawasi, mengendalikan serta menyalurkan perilaku warga masyarakat yang dipimpinnya.

Seorang pemimpin bangsa, harus aktif dalam menyalurkan ide-ide kecil masyarakat yang ia pimpin, tidak memilah mana yang didahulukan, ia harus bisa membagi sesuai dengan kebutuhan masyarakat itu sendiri.

Tidak ada tebang pilih, semua diberlakukan sama, baik itu dalam perlakuan hukum, dan hal lainnya, serta bisa memberikan aura positif dan aura semangat (optimisme) kepada masyarakat dalam segala bidang, dengan harapan ada nya peningkatan hasil dari proses optimisme tersebut.

3) Bertindak sebagai wakil kelompok di luar kelompok yang dipimpin.

Seorang pemimpin dipilih atas dasar pemilihan umum (pemilu) seluruh masyarakat mempunyai hak yang sama untuk melakukan pemilihan, sehingga nanti terpilihlah Presiden yang baru, dan tentunya dengan konstituennya yang berbeda juga.

Seorang pemimpin menurut Hendropuspiot, harus mempunyai kesadaran-kesadaran kemasyarakatan atau "sosial basis" yang mencakup susunan masyarakat serta "cultural focus"

${ }^{19}$ I Ketut Angga Irawan, "Persona Pemimpin Muda Di Era Revolusi Industri 4.0,” 2019, 1-10.

Al Qalam: Jurnal Ilmiah Keagamaan dan Kemasyarakatan Vol. 16, No. 1 Januari - Juni 2022 
masyarakat yang bersangkutan. Kehadiran pribadi-pribadi pemimpin yang membawa pengaruh besar terhadap warga masyarakat untuk menjauhkan diri dari penyimpangan yang merugikan kehidupan bersama. Puspito mengatakan bahwa kehadiran para pemimpin yang berwibawa dan berpengaruh dalam kelompok tersentu mempunyai dua arti lebih tinggi. ${ }^{20}$

"Seorang pemimpin mempunyai kelebihan dalam pengetahuan tentang norma-norma moral dan pola-pola kelakuan yang disepakati dan diterima oleh masyarakat. Termasuk peraturanperaturan tertulis dan tidak tertulis. Seorang pemimpin dipandang sebagai suri tauladan bagi bawahan, khususnya dalam kesetiaan pada kaidah-kaidah sosial umumnya dan peraturan-peraturan Negara kahususnya."

Pemimpin merupakan figur sentral dalam kelompok sosial atau masyarakat, sesuai dengan posisi yang ditempatinya dia memegang peran penting dalam mengatur kelangsungan hidup kelompok, seperti membina hubungan antar peribadi, menciptakan suasana yang harmonis, mengatasi ketegangan dan konflik. Istilah pemimpin mempunyai berbagai macam pengertian misalnya: Pertama, pemimpin adalah seorang pribadi yang memiliki kecakapan dan kelebihan khusus dalam suatu bidang, sehingga mampu mempengaruhi orang lain untuk bersama-sama melakukan aktivitas tertentu demi pencapaian tujuan. Kedua, sebabai mana yang dikatakan oleh Hendry Pratt Fairchild, pemimpin adalah seseorang yang memimpin dengan jalan memprakarsai tingkah laku sosial dengan mengatur, manunjukan, mengorganisasi, dan mengontrol usaha orang lain atau melalui "Prstise", kekuasaan atau posisi.

Ketiga, John Gage Alle mengatakan bahwa pemimpim adalah pemandu, penunjuk, penuntun dan komando, dan Keempat, pemimpin adalah kepala "Aktual" dari organisasi kota, dusun, atau 'sub-sub devisi' lainnya. Deliar Noer menggatakan: berbagai organisasi baik sosial, pendidikan, atau politik telah kita lihat berbagai sifat tiap organisasi itu, dimana kecenderungan yang mereka tekankan dalam pemikiran masing-masing adalah; "Sifat kecenderungan organisasi ini dibentuk oleh pimpinan organisasi serta lingkungan dimana organisasi itu bergerak."

\section{KESIMPULAN DAN SARAN}

Pemimpin pada hakikatnya adalah seorang yang mempunyai kemampuan untuk memepengaruhi perilaku orang lain di dalam kerjanya dengan menggunakan kekuasaan. Dalam kegiatannya bahwa pemimpin memiliki kekuasaan untuk mengerahkan dan mempengaruhi bawahannya sehubungan dengan tugas-tugas yang harus dilaksanakan.

Berbicara tentang pemimpin, pada hakikatnya setiap manusia adalah pemimpin dan setiap manusia akan diminta pertanggungjawabannya atas

\footnotetext{
${ }^{20}$ OC Hendropuspito, Sosiologi Agama (Yogyakarta: Kanisius, 2000).
} 
kepemimpinannya kelak. Manusia sebagai pemimpin minimal mampu memimpin dirinya sendiri. Setiap organisasi harus ada pemimpinnya, yang secara ideal dipatuhi dan disegani bawahannya. Oleh karena itu, harus adaseorang pemimpin yang mampu membawa bawahannya untuk mencapaitujuan individu, kelompok, dan organisasi. Kepemimpinan adalah ilmu dan seni mempengaruhi orang ataukelompok untuk bertindak seperti yang diharapkan untuk mencapai tujuansecara efektif dan efisien.

Dari uraian kepemimpinan dari basis agama, filsafat, psikologis dan sosiologis dapat diketahui bahwa teori kepemimpinan tertentu akan sangat mempengaruhi gaya kepemimpinan (Leadership Style), yakni pemimpin yang menjalankan fungsi kepemimpinannya dengan segenap filsafat, keterampilan dan sikapnya. Gaya kepemimpinan adalah cara seorang pemimpan bersikap, berkomunikasi, dan berinteraksi dengan orang lain dalam mempengaruhi orang untuk melakukan sesuatu. Gaya tersebut bisa berbeda-beda atas dasar motivasi, kuasa ataupun orientasi terhadap tugas atau orang tertentu. Diantara beberapa gaya kepemimpinan, terdapat pemimpin yang positif dan negatif, dimana perbedaan itu didasarkan pada cara dan upaya mereka memotivasi karyawan. Apabila pendekatan dalam pemberian motivasi ditekankan pada imbalan atau reward (baik ekonomis maupun nonekonomis) berartitelah digunakan gaya kepemimpinan yang positif. Sebaliknya jika pendekatannya menekankan pada hukuman atau punishment, berarti dia menerapkan gaya kepemimpinan negatif. Pendekatan kedua ini dapat menghasilakan prestasi yang diterima dalam banyak situasi, tetapi menimbulkan kerugian manusiawi.

Masalah kepemimpinan selalu memberi kan kesan menarik dari waktu ke waktu. Kepemimpinan ini memainkan peran penting dalam berbagai aktivitas organisasi. Dalam kepemimpinan ini, seorang pemimpin harus memberikan pengarahan-pengarahan terhadap usahausaha semua bawahan dalam mencapai tujuan organisasi.

Kepemimpinan dan penyesuaian terhadap perubahan merupakan tantangan terbesar yang dihadapi pemimpin saat ini. Pemimpin harus menggunakan gaya kepemimpinan yang paling efektif dalam mempengaruhi persepsi bawahan mengenai tujuan yang ingin dicapai dan cara untuk mencapainya. Peranan seorang pemimpin dalam hubungan antar manusia dalam bekerja sagat terkait dengan gaya kepemimpinan yang ditampilkannya. Kepemimpinan yang efektif akan mendorong bawahan untuk mengubah upaya menjadi kinerja. Pemimpin dalam organisasi yang berubah selalu berhadapan dengan pilihan terhadap gaya kepemimpinan yang mana yang tepat dan sesuai untuk diterapkan di organisasi. Seorang pemimpin diharapkan dapat menampilkan gaya kepemimpinan segala situasi tergantung kondisi dan situasi serta kepada bawahan mana yang dipimpinnya.

Al Qalam: Jurnal Ilmiah Keagamaan dan Kemasyarakatan Vol. 16, No. 1 Januari - Juni 2022 


\section{DAFTAR PUSTAKA}

Amrozi, Shoni Rahmatullah. Menggagas Pemimpin Masa Depan. Jember: Pena Salsabila, 2010. Anita, NMY, I W Karyasa, dan I Nyoman Tika. Filsafat Ilmu. Singaraja: Undiksha Press, 2013. Asmani, Jamal Ma'mur. Manajemen Pengelolaan dan Kepemimpinan Pendidikan Profesional: Panduan Quality Control bagi Para Pelaku Lembaga Pendidikan. Jogjakarta: DIVA Press, 2009.

Endraswara, Suwardi. Falsafah Kepemimpinan Jawa: Butir-Butir Nilai yang Membangun Karakter Seorang Pemimpin Menurut Budaya Jawa. Yogyakarta: Narasi, 2013.

Fatah, Syukur. Psikologi Pendidikan dengan Pendekatan Baru. Semarang: Rasail, 2008.

Hartono, Meilani. "Kepemimpinan Pendidikan Indonesia pada Era Milenium." Diterima dari https://pgsd. binus. ac. id/2018/11/23/kepemimpinan-pendidikan-indonesia-pada-eramilenium, 2018.

Hendropuspito, OC. Sosiologi Agama. Yogyakarta: Kanisius, 2000.

Hidayat, Ara, dan Imam Machali. Pengelolaan Pendidikan: Konsep, Prinsip, dan Aplikasi dalam Mengelola Sekolah dan Madrasah. Jakarta: Pustaka Educa, 2012.

Irawan, I Ketut Angga. "Persona Pemimpin Muda Di Era Revolusi Industri 4.0," 1-10, 2019.

Kartono, Kartini. Pemimpin dan Kepemimpinan: Apakah Kepemimpinan Abnormal Itu? Jakarta: Rajawali Pers, 2014.

Liliweri, Alo. Wacana Komunikasi Organisasi. Bandung: Mandar Maju, 2004.

Luthans, Fred, James B Avey, Bruce J Avolio, dan Suzanne J Peterson. "The Development And Resulting Performance Impact Of Positive Psychological Capital." Human resource development quarterly 21, no. 1 (2010): 41-67.

Luthans, Fred, Bruce J Avolio, James B Avey, dan Steven M Norman. "Positive Psychological Capital: Measurement and Relationship With Performance and Satisfaction." Personnel psychology 60, no. 3 (2007): 541-72.

Mastuti, Fauziyah, dan Tukiman Taruno. "Pola Kepemimpinan Organisasi Pendidikan di Jawa Tengah Ditinjau dari Filsafat Pendidikan Menurut Kaplan,” 2009.

Yuniarti, Anita, dan Desi Yustari Muchtar. "Pengaruh Modal Psikologis Dan Persepsi Gayakepemimpinan Transformasional Terhadap Workplace Well Being." TAZKIYA: Journal of Psychology 4, no. 2 (2019).

Al Qalam: Jurnal Ilmiah Keagamaan dan Kemasyarakatan Vol. 16, No. 1

Januari - Juni 2022 